\title{
A NEW ROBUST AND COMPUTATIONALLY EFFICIENT NUMERICAL MODEL FOR THE ANALYSIS OF BEAM TYPE STRUCTURES
}

\author{
Ante Mihanović; Hrvoje Smoljanović; \\ Boris Trogrlić; Ante Munjiza \\ University of Split, Faculty of Civil Engineering, Architecture and Geodesy; \\ Matice hrvatske 15, 21000 Split, Croatia
}

\begin{abstract}
This paper presents a new numerical model for the analysis of beam type structures. The model uses two-noded rotation free finite elements and takes into account material non-linearity, finite displacements, finite rotations and finite strains. The presented numerical model has been implemented into the open source 'Yfdem', which is based on the Combined Finite Discrete Element Method. The performance of the new numerical model was demonstrated on simple benchmark tests, by a comparison with known experimental and analytical results.
\end{abstract}

Keywords: numerical model; beam structures; finite-discrete element method.

\section{INTRODUCTION}

Beam type structural elements, which are constituent elements of many constructions, are elements in which the length is considerably more pronounced than the width and the height of the cross-section. Beam elements can be flat, supporting transverse load through bending, or curved, supporting transverse loads trough a combined action of bending and axial force.

Throughout history, a number of numerical models have been developed for the analysis of beam structures, most of which are based on the finite element method (FEM). The finite element method formulation of the problem results in a system of algebraic equations. To solve the problem, it subdivides a large domain into smaller parts 
that are called finite elements. The method yields approximate displacement field over finite elements at the finite number of points by using shape functions. Simple equations obtained over these finite elements are assembled into a larger system of equations that models the entire problem. Solving a large system of equations, especially if material non-linearity, finite rotations and finite displacements are taken into account, can become computationally very demanding and time-consuming, causing additionally problems due to numerical instabilities.

Due to its long tradition, a number of numerical models based on FEM have been developed and are distinguished in type of finite elements, the structure of which is discretized, and in type of constitutive law of materials that can be linear and non-linear.

The simplest element formulations, which use lower order polynomial as shape functions for approximating node displacement, result in overly stiff behaviour known as the locking phenomenon. This phenomenon arises due to an inability of the formulations to describe a pure bending deformation. The solution to this problem has emerged in the form of a coupled polynomial, mixed trigonometric polynomial and in higher-order-polynomial shape functions for approximating displacement field over finite elements [1-6]. Finite elements proposed so far are mainly dependent on the shape of the beam element. They are usually not established or are even found deficient for different beam configurations. In search for better computational efficiency, there has also been development in rotation-free finite elements [7-11]. These elements manage to remove rotational degrees of freedom by increasing the interpolation domain outside of the area of integration domain, and therefore achieve significant simplification of the initial problem.

The main purpose of this paper is to present a simple, robust and computationally efficient numerical model for the analysis of beam type structures. The model is based on two-noded rotation free finite elements taking into account non-linear material behaviour, finite displacements, finite rotations and finite strains. The discretization of the structure with a detailed description of the axial and bending carrying mechanism of finite elements are presented. Proposed numerical algorithms have been implemented into the open source 'Yfdem', which is based on combined finite discrete element method (FDEM) presented by Munjiza [12-15]. Subsequently, verification and validation of the proposed numerical model have been performed on several examples by comparing the obtained numerical results with the known analytical and experimental results from literature.

\section{PROPOSED NUMERICAL MODEL}

This chapter presents a numerical algorithm for the analysis of beam type structures, which, inter alia, takes into account material non-linearity, finite displacement and 
finite rotations. Detailed information regarding the discretization of the structure and the calculation of nodal forces due to the bending and axial deformation are shown below.

\subsection{Discretization of the structure}

Within the presented numerical model, the structure has been discretized with twonoded finite elements. The mass of the structure is concentrated in the finite element nodes as shown in Fig. 1.

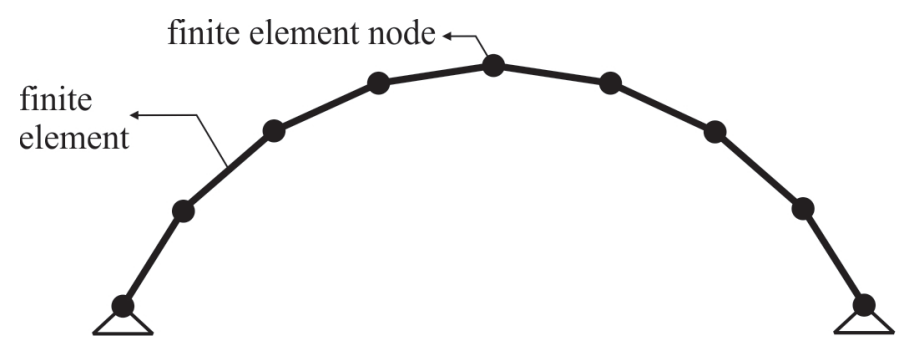

Fig. 1. Discretization of structure

SI. 1. Diskretizacija konstrukcije

\subsection{Calculation of nodal forces due to axial and bending carrying mechanisms}

For the purposes of calculating the axial and bending deformation and the calculation of nodal forces, the observed node $\mathrm{B}$ is considered together with its two neighbouring nodes $-\mathrm{A}$ and $\mathrm{C}-$ as shown in Fig. 2.

Based on the known coordinates of the nodes at any time step, it is possible to calculate the radius of the curvature of the circle passing through the nodes $\mathrm{A}, \mathrm{B}$ and $\mathrm{C}$ according to the relation:

$$
r=\frac{d}{2 \sin \varphi}
$$

Here, $d$ and $\varphi$ are the length between the adjacent nodes and the angle between the finite elements in the node B, respectively (see Fig. 2.). 


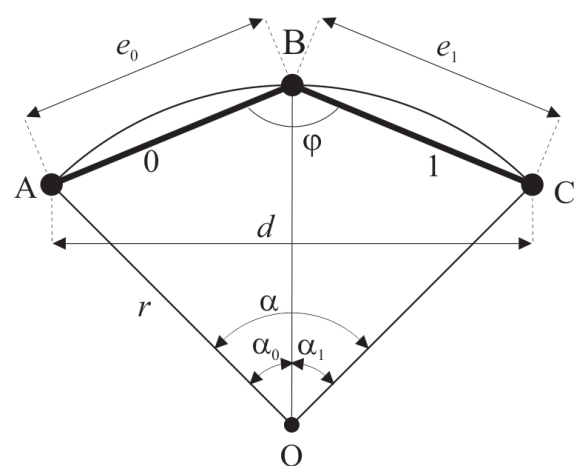

Fig. 2. Observed finite element node together with two neighbouring nodes

Sl. 2. Promatrani čvor konačnog elementa zajedno sa susjednim čvorovima

Based on the known radius of curvature of the circle and the distance between adjacent nodes, it is possible to calculate the angles $\alpha_{0}, \alpha_{1}$ and $\alpha$ (see Fig. 2.) at any time step according to the following relations:

$$
\begin{aligned}
& \alpha_{0}=\operatorname{acos}\left(\frac{1-e_{0}^{2}}{2 r^{2}}\right) \\
& \alpha_{1}=\operatorname{acos}\left(\frac{1-e_{1}^{2}}{2 r^{2}}\right) \\
& \alpha=\alpha_{0}+\alpha_{1}
\end{aligned}
$$

Within the presented numerical algorithm, the cross-section has been divided into layers as shown in Fig. 3. For each layer, it is possible to calculate its length $l_{i}$ at any time step in accordance with the following relation:

$$
l_{i}=r_{i} \alpha
$$

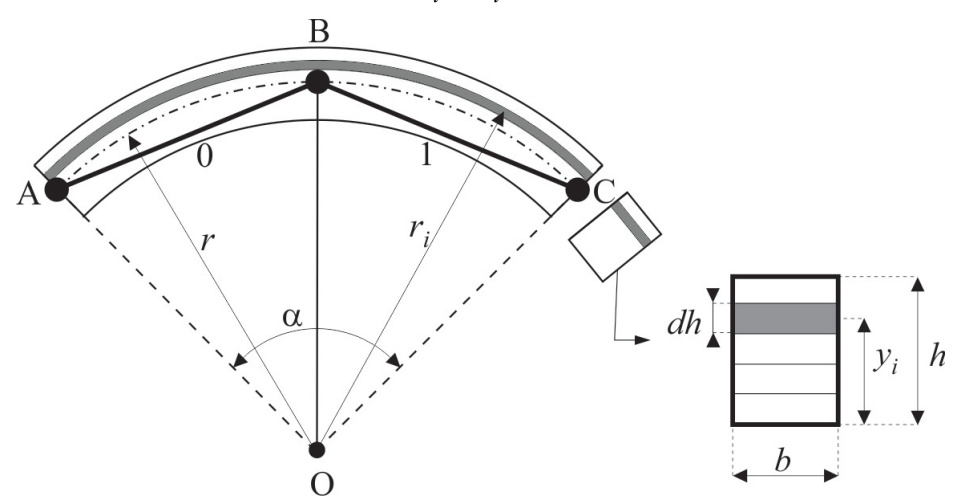

Fig. 3. Cross-section of the structures with layers

SI. 3. Uslojeni poprečni presjek 
Here, $r_{i}$ is the radius of the curvature of the observed layer (see Fig. 3) given by:

$$
r_{i}=r-\frac{h}{2}+y_{i}
$$

In the previous relation, $y_{i}$ is the distance between the centre of the layer and the bottom of the cross, while $h$ is the height of the cross-section as shown in Fig. 3. Based on the length of the layers in initial $l_{i, i}$ and current $l_{i, c}$ configuration, it is possible to calculate the strain of the layer according to the following relation:

$$
\varepsilon_{i}=\frac{l_{i, c}-l_{i, i}}{l_{i, i}}
$$

Taking into account the constitutive law of material given in relation between stress and strain, based on the known strain $\varepsilon_{i}$, it is possible to obtain stress $\sigma_{i}$ in the centre of the layer. It is important to note that an arbitrary relation can be chosen between strain and strain. Differential force $d n_{i}$ acting at the centre of the layer can be obtained according to the following relation:

$$
d n_{i}=b d h \sigma_{i}
$$

Here, $b$ and $d h$ are the width and the thickness of the layer, respectively (see Fig. 3.). Total axial force acting on the centre of the gravity of the cross-section in the node B (see Fig. 4.) is obtained according to:

$$
n_{B}=\sum_{i=1}^{n} d n_{i}
$$

Here, index $n$ in the summation relates to the number of layers.

The procedure described above is repeated for the nodes $\mathrm{A}$ and $\mathrm{C}$, which yields axial force in node $\mathrm{A} n_{A}$ and axial force in node $\mathrm{C} n_{C}$ as shown in Fig. 4a. Finally, axial forces in finite elements 0 and 1 are given by:

respectively.

$$
n_{0}=\frac{n_{A}+n_{B}}{2} ; n_{1}=\frac{n_{B}+n_{C}}{2},
$$

The moment at the centre of the gravity of the cross-section in the node B (see Fig. $4 \mathrm{~b}$.) is obtained according to relation:

$$
m_{B}=\sum_{i=1}^{n} d n_{i}\left(y_{i}-\frac{h}{2}\right)
$$

Here, $h$ is the height of the cross-section. 


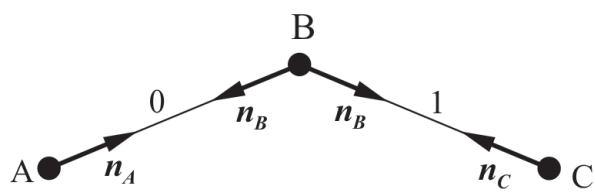

(a)

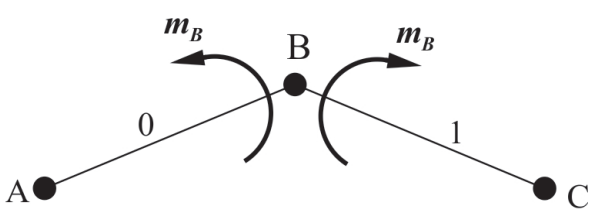

(b)

Fig. 4. (a) Axial forces in nodes $A, B$ and $C$ and (b) moment in node $B$

Sl. 4. (a) Uzdužne sile u čvorovima A, B i C i (b) moment u čvoru B

Axial forces in finite elements 0 and 1 are transferred in the form of equivalent nodal forces in nodes A, B and C as shown in Fig. 5a, while the moment in observed node $\mathrm{B}$ is transferred in the form of pair of forces in nodes A, B, and C as shown in Fig. 5b.

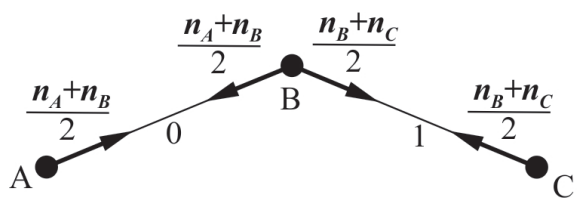

(a)

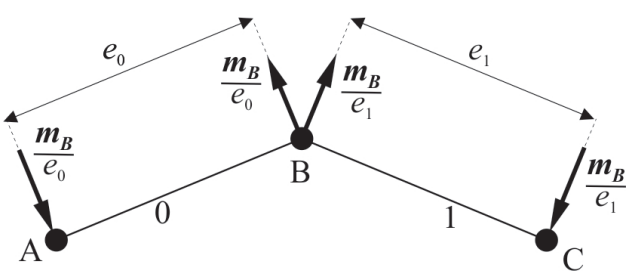

(b)

Fig. 5. Equivalent nodal forces due to: (a) axial force in finite elements 0 and 1;

(b) moment in node B

SI. 5. (a) Ekvivalentne čvorne sile uslijed: (a) uzdužne sile u konačnom elementu 0 i 1;

(b) momenta u čvoru B

If node $\mathrm{A}$ is boundary node, axial force in node $\mathrm{A}$ equals $n_{B}$. Finally, if node $\mathrm{C}$ is boundary node, axial force in node $\mathrm{C}$ equals $n_{C}$. Equivalent nodal forces due to axial force in finite elements 0 and 1 in case when node $\mathrm{A}$ and $\mathrm{C}$ are boundary nodes are shown in Fig. $6 \mathrm{a}$ and Fig. 6b, respectively. The procedure described above is repeated for all nodes.

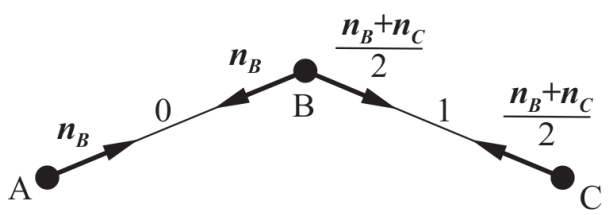

(a)

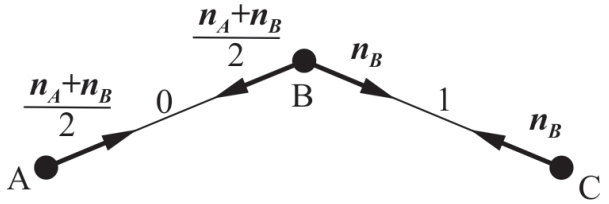

(b)

Fig. 6. Equivalent nodal forces due to axial force in finite elements 0 and 1 in case where boundary node is: (a) node A; (b) node B

SI. 6. (a) Ekvivalentne čvorne sile uslijed uzdužne sile u konačnim elementima 0 i 1 u slučaju kada je krajnji čvor: (a) čvor A; (b) čvor B 


\subsection{Clamped boundary condition}

In the context of the FDEM, based on which the presented numerical model has been developed, nodes only have translational degrees of freedom. Taking this fact into account, the question is how to achieve clamped boundary condition. In actual implementation, the clamped boundary condition, for example in node B (see Fig. 7.), can be achieved by implementing fictive node near the clamped boundary as shown in Fig. 7. As the fictive node, which lies in the tangent on the structure at the clamped boundary, tends to the clamped boundary, the tangent on the circle passing through nodes $\mathrm{A}, \mathrm{B}$ and $\mathrm{C}$ converges to the tangent on the structure at clamped boundary as shown in Fig. 7. In the current configuration, there are some discrepancies between theoretical and calculated curvature, since the tangent on the structure at the boundary node does not coincide with the tangent of the circle passing through the fictive node A, and nodes B and C. It can be shown that if the length of the fictive element 0 (see Fig. 7) is over one thousand times smaller than the length of the finite element 1 (see Fig. 7), the discrepancy is smaller than $0.01 \%$.

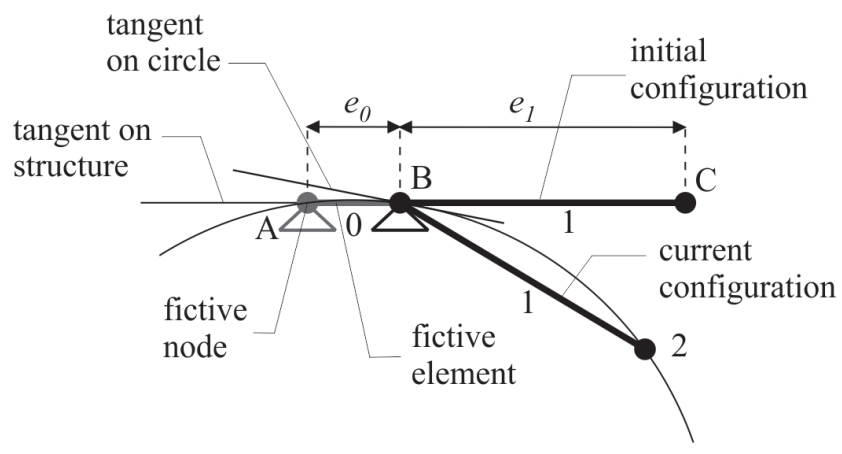

Fig. 7. Clamped boundary in actual implementation

SI. 7. Upeti rubni uvjet u stvarnoj implementaciji

\subsection{Nodal forces due to dumping}

In the proposed numerical model, a viscous type of damping is adopted, in which the damping forces, whose intensity is proportional to the velocity and damping coefficient $\mu$, are linearly distributed over the finite elements. The proposed numerical model differentiates the dumping forces, which act in direction of the construction line, and damping forces, which act in direction normally on the construction. For the purpose of calculating equivalent nodal forces due to dumping, the velocity of the nodes of the 
finite element has been split into the components in direction tangential and orthogonal to the finite element as shown in Fig. 8. Equivalent nodal forces in nodes A and B are thus given by:

$$
\begin{aligned}
& \mathbf{f}_{B, \text { dump }}=-\mu_{\text {nor }}\left(\mathbf{v}_{B, \text { nor }} \frac{e_{0}}{3}+\mathbf{v}_{A, \text { nor }} \frac{e_{0}}{6}\right)-\mu_{\tan }\left(\mathbf{v}_{B, \tan } \frac{e_{0}}{3}+\mathbf{v}_{A, \tan } \frac{e_{0}}{6}\right) \\
& \mathbf{f}_{A, \text { dump }}=-\mu_{\text {nor }}\left(\mathbf{v}_{B, \text { nor }} \frac{e_{0}}{6}+\mathbf{v}_{A, \text { nor }} \frac{e_{0}}{3}\right)-\mu_{\tan }\left(\mathbf{v}_{B, \tan } \frac{e_{0}}{6}+\mathbf{v}_{A, \tan } \frac{e_{0}}{3}\right)
\end{aligned}
$$

Here, $\mu_{n o r}$ and $\mu_{\text {tan }}$ are normal and tangential dumping coefficients.

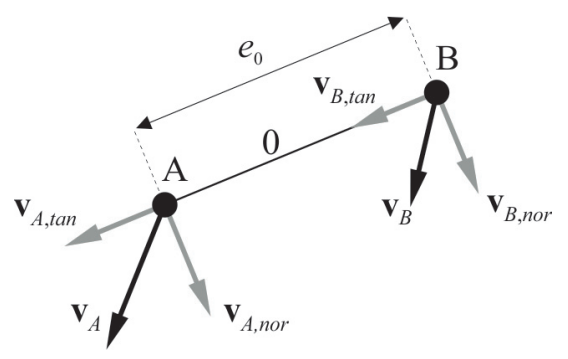

Fig. 8. Normal and tangential component of node velocity

Sl. 8. Normalna i tangencijalna komponenta brzine u čvoru

The procedure described above is repeated for all finite elements.

\subsection{Time integration of equation of motion}

The shape of a beam element and its position in space at any time step is given by the current coordinates of the finite element nodes $x_{i}$, where $i$ is associated with the degree of freedom. Similarly, the velocity field and acceleration field have been defined by nodal velocities $v_{i}$ and nodal accelerations $a_{i}$, respectively [12].

In the context of the FDEM, a time integration scheme in an explicit form is applied to each node and each degree of freedom. Nodal forces resulting from axial carrying mechanism, bending carrying mechanism, external loads and dumping forces are all added together, and a total nodal force $f_{i}$ associated with each degree. The dynamic equilibrium for each degree of freedom is therefore given by:

$$
m_{i} a_{i}=f_{i}
$$

Here, $m_{i}$ is the mass associated with each degree of freedom. 
For the integration of the above equation, a central difference time integration scheme based on explicit integration of the governing equation for each degree of freedom has been employed. The scheme can be formulated as follows:

$$
\begin{aligned}
& v_{i, t+\Delta t / 2}=v_{i, t-\Delta t / 2}+\Delta t f_{i, t} / m_{i} \\
& x_{i, t+\Delta t}=x_{i, t}+\Delta t v_{i, t+\Delta t / 2}
\end{aligned}
$$

Here, $\Delta \mathrm{t}$ is a time step.

A schematic flowchart that describes the overall numerical procedure has been shown in Fig. 9. It is worth pointing out that the proposed numerical procedure does not require either stiffness or mass matrices to be assembled, which makes it suitable for parallel programming.

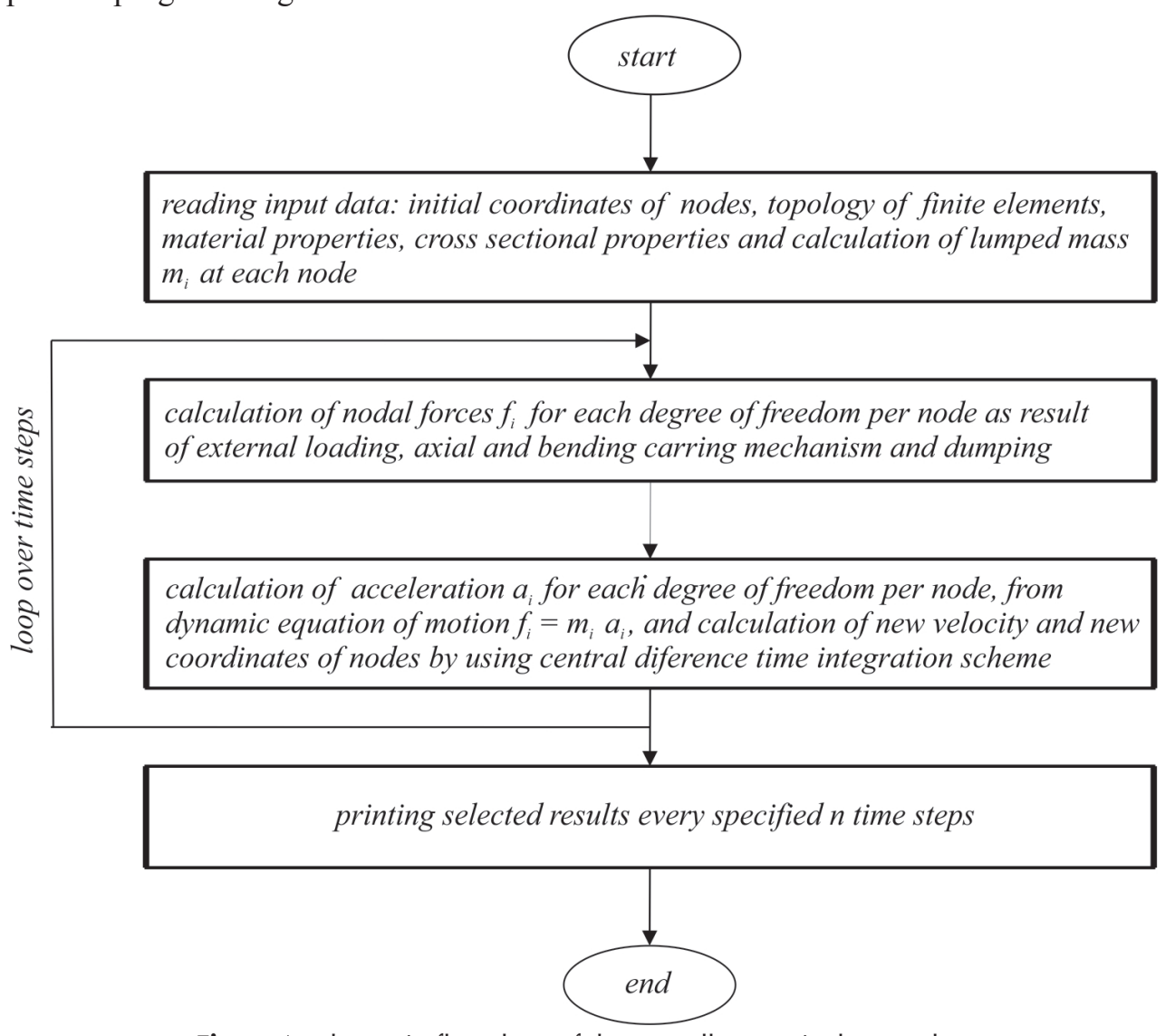

Fig. 9. A schematic flowchart of the overall numerical procedure

SI. 9. Shematski dijagram prethodno opisanog numeričkog postupka 


\section{VALIDATION OF THE FDEM NUMERICAL MODEL}

The model described above has been implemented into the open source FDEM package - Yfdem [12]. The validation of the model has been performed on several examples by comparing the obtained results with the known analytical and experimental results obtained in the literature.

\subsection{Cantilever exposed to bending moment at the free end}

The cantilever beam exposed to bending moment at the free end as shown in Fig. $10 \mathrm{a}$, has been chosen in order to investigate the relative error of calculated moment in cross-section in dependence on the number of subdivisions per high of the cross-section.

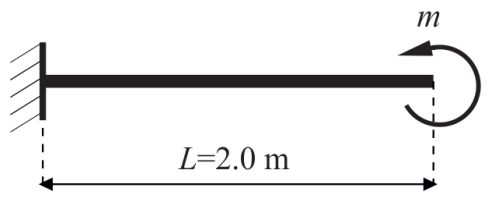

(a)

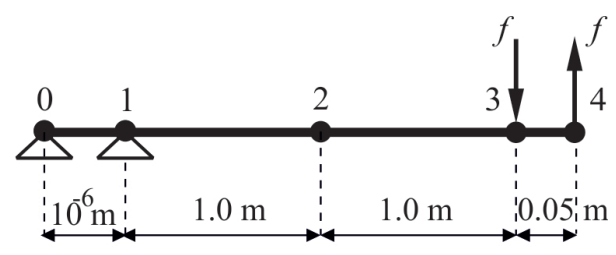

(b)

Fig. 10. Cantilever exposed to bending moment at the free end: (a) geometry; (b) discretization

SI. 10. Konzola opterećena momentom na slobodnom kraju: (a) geometrija; (b) diskretizacija

The cantilever was discretized with four finite elements and five nodes as shown in Fig. $9 \mathrm{~b}$. The finite element 0 of length $1 \cdot 10^{-6} \mathrm{~m}$ with hinged nodes 0 and 1 has been used for modelling the clamped boundary condition in node 1, while the finite element 3 of length $0.05 \mathrm{~m}$ with a pair of forces in nodes 3 and 4 has been used for modelling of the bending moment in node 3 , which equals:

$$
m / k N m=0.05 f / k N
$$

The modulus of elasticity of the cantilever equalled $E=210 \mathrm{GPa}$, while the width $b$ and the height $h$ of the cross-section were adopted in the amounts of $1.0 \mathrm{~m}$ and $0.1 \mathrm{~m}$, respectively. The following relation explains the analytical relationship between bending moment and curvature in cross-section:

$$
m_{a n}=\frac{1}{r} E I
$$

Here, $I$ is the moment of inertia of the cross-section given by: 


$$
I=\frac{b h^{3}}{12}=\frac{1.0 \mathrm{~cm} \cdot 0.1 \mathrm{~cm}^{3}}{12}=8.333 \cdot 10^{-5} \mathrm{~m}^{4}
$$

Including the relation (15) in (14) and taking into account the modulus of elasticity that equals $E=210 \mathrm{GPa}$ yields as follows:

$$
m_{a n} /(\mathrm{N} / \mathrm{m})=17500 \frac{1}{r / \mathrm{m}}
$$

The relation between the moment at the free end and curvature in node 2 obtained with the proposed numerical model for a different number of subdivisions $n$ per height of the cross-section has been shown in Fig. 11. From the presented results, it can be seen that by increasing the number of subdivisions per height of the cross-section, the numerical solution converges to the analytical one.

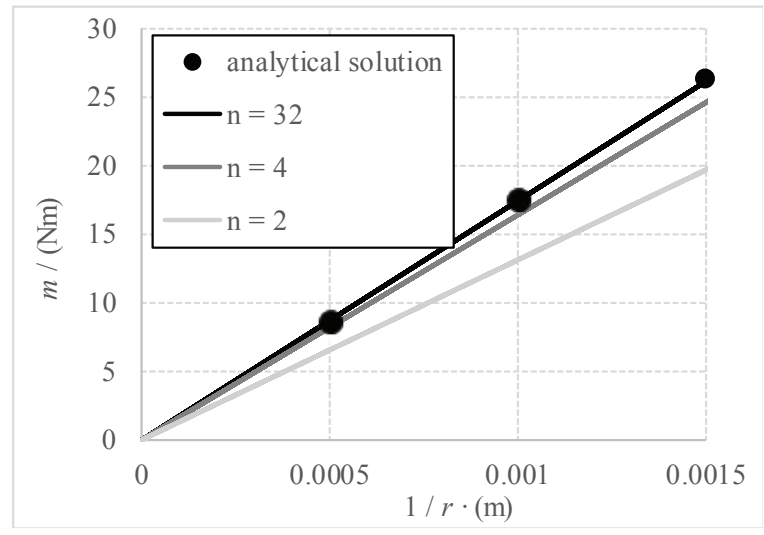

Fig. 11. Comparison of curvature in node 2 with analytical solution

SI. 11. Usporedba zakrivljenosti u čvoru $2 \mathrm{~s}$ analitičkim rješenjem

Relative error in calculating the moment in node 2 in comparison with the analytical solution obtained according to the following relation:

$$
\text { relativeerror }=\frac{m-m_{a n}}{\mathrm{~m}_{\mathrm{an}}} \cdot 100
$$

has been shown in Fig. 12. It can be seen that in a number of subdivisions higher than 30, relative error is less than $0.1 \%$. 


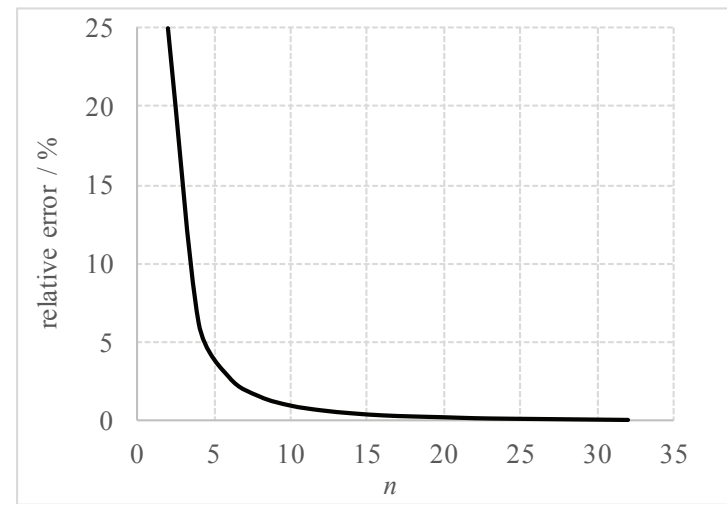

Fig. 12. Relative error of the moment in node 2 in comparison with analytical solution

Sl. 12. Relativna pogreška momenta u čvoru 2 u usporedbi s analitičkim rješenjem

\subsection{A simply supported beam under self-weight}

A simply supported beam under self-weight, whose geometry has been shown in Fig. 13, has been chosen to analyse relative error in numerical solution obtained with presented numerical model in dependence of the number of finite elements per beam length. The width of the cross-section equalled $100 \mathrm{~cm}$, while the height of cross-section varied in the amounts of $50 \mathrm{~mm}$ and $200 \mathrm{~mm}$. The modulus of beam elasticity equalled $E=210 \mathrm{GPa}$, while the density $\rho$ and gravity constant $g$ were adopted in the amounts of $7,850 \mathrm{~kg} / \mathrm{m}^{3}$ and $10 \mathrm{~m} / \mathrm{s}^{2}$, respectively.

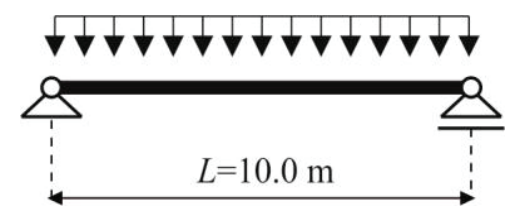

Fig. 13. Simply supported beam under self-weight

Sl. 13. Jednostavna greda opterećena vlastitom težinom

The discretization of the beam was performed by using $2,4,8$ and 16 finite elements, which means that the lengths $l$ of the finite elements were $L / 2, L / 4, L / 8$ and $L / 16$, respectively. Starting from an initially flat geometry, the beam oscillates due to its selfweight, and subsequently, as a result of damping, finds an equilibrium position as shown in Fig. 14. 


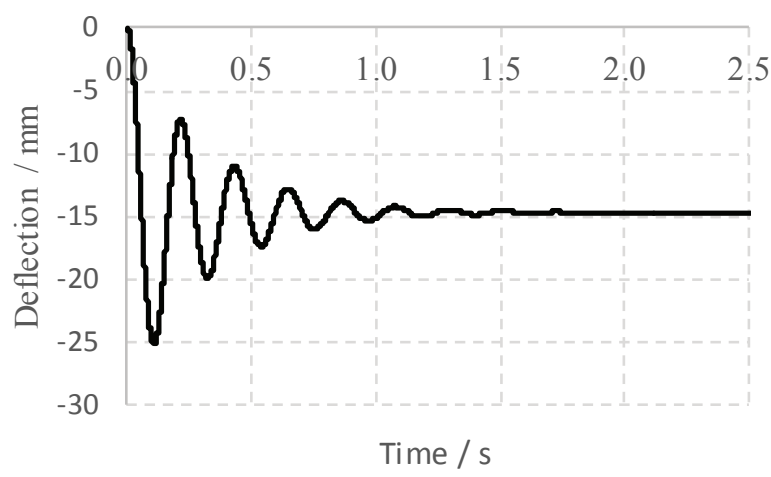

Fig. 14. Time-midspan deflection response for beam discretized with 16 finite elements and damping coefficient $\mu_{\text {nor }}=\mu_{\text {tan }}=10000 \mathrm{kNm}^{2} / \mathrm{s}$.

SI. 14. Progib centra grede u vremenu za diskretizaciju od 16 konačnih elemenata i prigušenje $\mu_{\text {nor }}=\mu_{\tan }=10000 \mathrm{kNm}^{2} / \mathrm{s}$.

The equilibrium deflections at the midspan of the beam obtained with presented numerical model together with numerical solutions obtained by the ABAQUS programme package have been shown in Table 1. The numerical solutions from ABAQUS have been obtained by using 100 three-noded quadratic beam finite elements. Relative errors of the numerical results obtained with the proposed numerical model in comparison with the numerical solutions obtained by ABAQUS have been shown in Table 2.

Table 1

Deflection at the midspan of the beam in $(\mathrm{mm})$

\begin{tabular}{lcc}
\hline Beam thickness & $50 \mathrm{~mm}$ & $200 \mathrm{~mm}$ \\
\hline FDEM $(I=L / 2)$ & 279.73 & 17.538 \\
FDEM $(I=L / 4)$ & 244.84 & 15.346 \\
FDEM $(I=L / 8)$ & 236.12 & 14.798 \\
FDEM $(I=L / 16)$ & 233.94 & 14.661 \\
\hline ABAQUS & 232.999 & 14.601 \\
\hline
\end{tabular}

From the presented results, it can be observed that as the number of the finite elements increases, the numerical solutions converge to those obtained by ABAQUS and the error of approximation decreases with $l^{2}$. It has also been observed that the influence of beam thickness on error is negligible, which indicates that the presented numerical model does not suffer from the locking phenomenon related to the length to thickness ratio of the beam. 
Table 2

Relative error of the beam in comparison with numerical solution obtained by ABAQUS in (\%)

\begin{tabular}{lcc}
\hline Beam thickness & $50 \mathrm{~mm}$ & $200 \mathrm{~mm}$ \\
\hline FDEM $(I=L / 2)$ & 20.06 & 20.11 \\
FDEM $(I=L / 4)$ & 5.08 & 5.10 \\
FDEM $(I=L / 8)$ & 1.36 & 1.35 \\
FDEM $(I=L / 16)$ & 0.40 & 0.41 \\
\hline
\end{tabular}

\subsection{Reinforced concrete beams}

Reinforced concrete beams exposed to monotonic increasing loading condition, with the known experimental results taken from literature [16], have been used for additional validation of the presented numerical model. The experimental programme conducted by Alca et al. [16] included 12 reinforced concrete beams subjected to a fourpoint bending test as shown in Fig. 15. Three depths of beams have been used: namely $230 \mathrm{~mm}$ (small beam); $360 \mathrm{~mm}$ (medium beam); and $515 \mathrm{~mm}$ (large beam). These have been combined with two concrete strengths: lower strength concrete (cylinder strength of $50 \mathrm{MPa}$ ), and higher strength concrete (cylinder strength of $90 \mathrm{MPa}$ ).

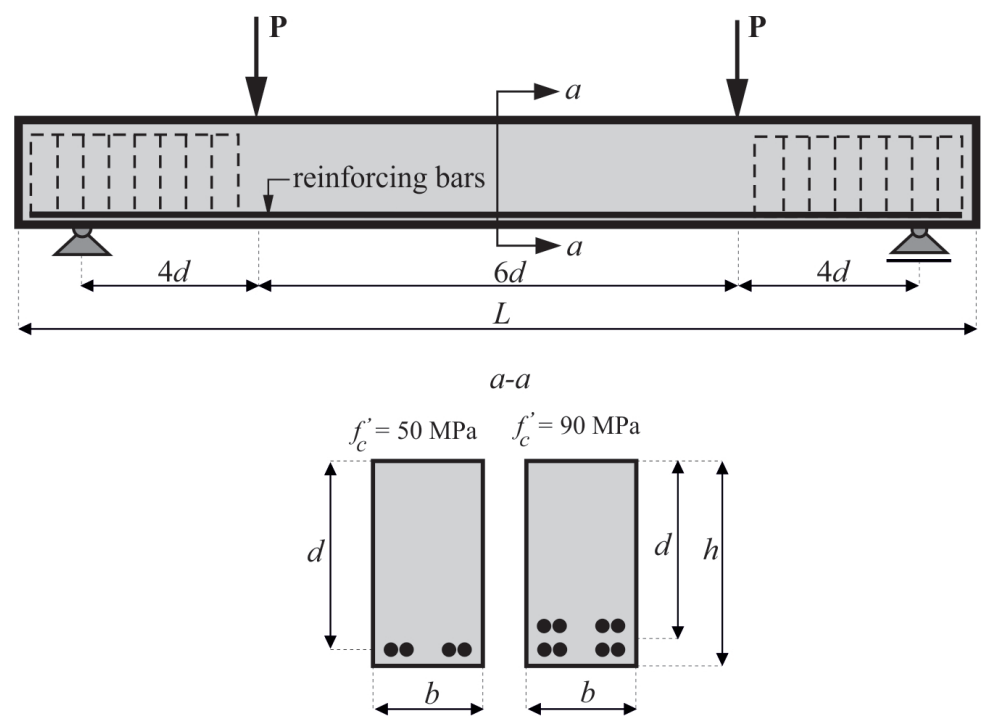

Fig. 15. Reinforced concrete beams exposed to monotonic increasing loading condition with cross-sections

SI. 15. Jednostavna armirano betonska greda izložena monotono rastućem opterećenju sa poprečnim presjecima 
In this work, only four beams were used, namely SL1, SH1, LL1 and LH1. Two letters and number designate each beam. The first letter $\mathrm{S}$ or $\mathrm{L}$ refers to small or large beam. The second letter L or $\mathrm{H}$ refers to low or high strength concrete. The geometric characteristic of these beams have been summarised in Table 3.

Alca et al. [16] have tested two beams of each type to failure (letter 1 or 2). Material properties for the first set of beams have been presented in Table 4.

\section{Table 3}

Beam geometry

\begin{tabular}{cccccc}
\hline Beam & $\varnothing / \mathrm{mm}$ & $b / \mathrm{mm}$ & $d / \mathrm{mm}$ & $h / \mathrm{mm}$ & $L / \mathrm{mm}$ \\
\hline SL1 & 16 & 150 & 230 & 282 & 3740 \\
SH1 & 16 & 150 & 230 & 302 & 3740 \\
LL1 & 35.7 & 335 & 515 & 630 & 8380 \\
LH1 & 35.7 & 335 & 515 & 630 & 8380 \\
\hline
\end{tabular}

\section{Table 4}

Beam material properties

\begin{tabular}{cccc}
\hline Beam & $f_{c}^{\prime} / \mathrm{MPa}$ & $f_{y} / \mathrm{MPa}$ & $\square / \%$ \\
\hline SL1 & 51.1 & 410 & 2.32 \\
SH1 & 90.1 & 410 & 4.64 \\
LL1 & 54.2 & 409 & 2.32 \\
LH1 & 90.3 & 406 & 4.64 \\
\hline
\end{tabular}

For the purpose of numerical analysis with the presented numerical model, the structure has been discretized with 28 finite elements as shown in Fig. 16. The beams have been modelled from support to support, and the overhang beyond the supports has been ignored.

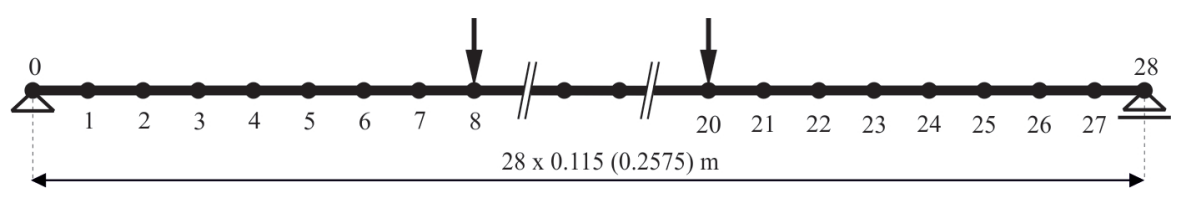

Fig. 16. Discretization of small and large reinforced concrete beams.

Values in brackets corresponds to large beam

SI. 16. Diskretizacija velike i male armirano betonske grede. Vrijednosti u zagradi odgovaraju velikoj gredi 
For all beams, the following approximation for the stress-strain curve for concrete has been adopted (as shown in Fig. 17a):

$$
\sigma=E \varepsilon-\frac{E^{2}}{4 f_{s}} \varepsilon^{2}
$$

Here, $\sigma$ is stress, $\varepsilon$ is strain, while $f_{s}$ is compression strength of concrete, which is adopted in amount of $44.77 \mathrm{MPa}$ for lower strength beams and $76.70 \mathrm{MPa}$ for higher strength beams. Stress in each of the bars has been obtained from strain using the bilinear stressstrain curve for steel as shown in Fig. 17b.

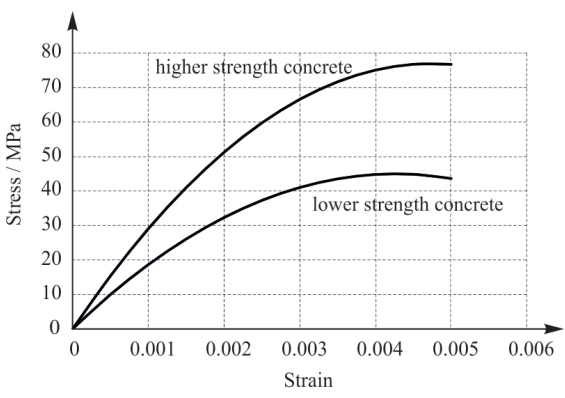

(a)

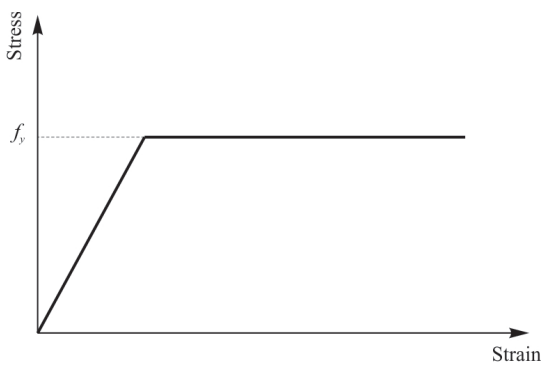

(b)

Fig. 17. Adopted stress strain curves for: (a) concrete; (b) reinforcing bars

SI. 17. Usvojene krivulje naprezanje-deformacija za: (a) beton; (b) armaturne šipke

Fig. 18 shows the comparison of numerical results obtained with presented numerical model with experimental results from Alca et al. [16] for small and large beams, for both lower and higher strength concrete.

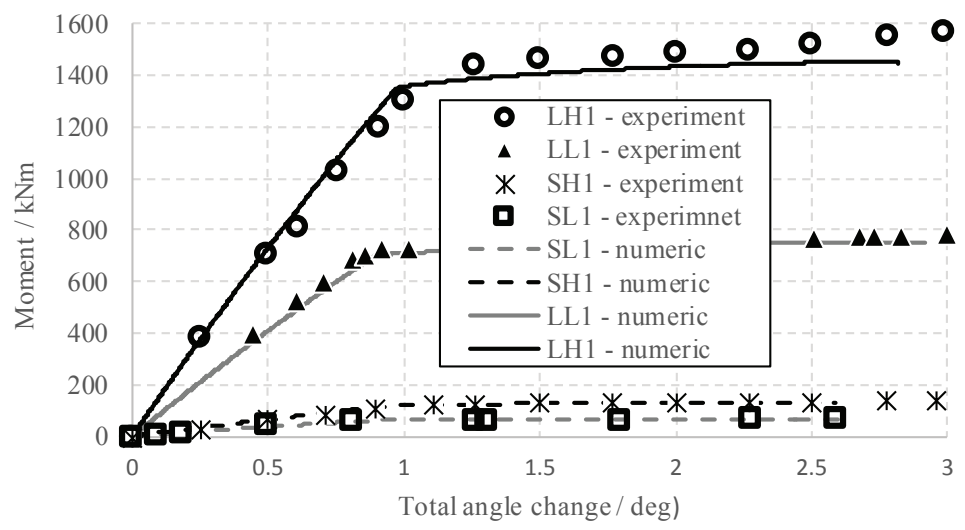

Fig. 18. Comparison of experimental and numerical moment-rotation curves SI. 18. Usporedba numeričke i eksperimentalne veze moment-rotacija 
For both experimental and numerical results, the bending moment at midspan versus total angle change has been shown. For all beams, the total angle change in both experimental and numerical results has been measured over a length of $3.7 d$. In both cases, good agreement can be seen between the two sets of results. This applies to both bending moments and ultimate rotations.

\section{CONCLUSIONS}

This paper presents a new robust numerical model for the two-dimensional analysis of beam type structures. The model uses two-noded rotation free finite elements. Detailed information related to axial and bending carrying mechanism has been presented in the paper in brief, together with numerical procedure for the time integration of equation of motion. The proposed algorithms have been implemented into the existing opensource 'Yfdem.' Package, based on a combined finite-discrete element method. The performance of the model has been demonstrated on simple benchmark tests by comparing the results obtained by the proposed numerical model with known analytical, numerical and experimental results available from literature.

Based on the proposed numerical algorithms and presented benchmark tests, concluding remarks can be drawn as follows:

- The model is based on two-noded rotation free finite elements, which enables efficient representation of any arbitrary geometry.

- The model enables the analysis of flat beams and beams with large initial curvature.

- The proposed model takes into account arbitrary non-linear material model, and is also suitable for the analysis of reinforced concrete structures.

- Due to defined local coordinate systems in the initial and current configuration, the proposed numerical model takes into account finite displacements, finite rotations and geometrical non-linearity.

- The main advantage of the presented model lies in the simplicity of its formulation. The presented numerical model requires neither stiffness nor mass matrices to be assembled; this makes it suitable for parallel programming.

- The results obtained by the presented numerical model show good agreement with the analytical, numerical and experimental results available from literature.

Furthermore, the model is easily upgradable for the analysis of three structures and parallel programming, which is yet another advantage of using the FDEM model. 


\section{References}

[1] Raveendranath P, Gajbir S, Pradhan B. Free vibration of arches using a curved beam element based on a coupled polynomial displacement field. Computers \& Structures 2000: 74 (4); 583-590.

[2] Kim JG, Park YK. Hybrid-mixed curved beam elements with increased degrees of freedom for static and vibration analyses. International Journal for Numerical Methods in Engineering 2006: 68; 690-706.

[3] Tang YQ, Zhou ZH, Chan SL. An accurate curved beam element based on trigonometrical mixed polynomial function. International Journal of Structural Stability and Dynamics 2013: 13 (04); 2525-2540.

[4] Pan KQ, Liu JY. Geometric nonlinear dynamic analysis of curved beams using curved beam element. Acta Mechanica Sinica 2011: 27 (6); 1023-1033.

[5] Santos HAFA. A novel updated Lagrangian complementary energy-based formulation for the elastica problem: force-based finite element model. Acta Mechanica 2015: 226 (4); 11331151 .

[6] Trogrlić B, Mihanović A. The comparative body model in material and geometric nonlinear analysis of space R/C frames. Engineering Computations 2008, 25: 155-171

[7] Phaal R, Calladine CR. A simple class of finite elements for plate and shell problems. I: Elements for beams and thin flat plates. International Journal for Numerical Methods in Engineering 1992: 35 (5); 955-977.

[8] Flores FG, Onate E. Rotation-free element for the non-linear analysis of beams and axisymmetric shells. Computer Methods in Applied Mechanics and Engineering 2006: 195 (41-43); 5297-5315.

[9] Zhou YX, Sze KY. A rotation-free beam element for beam and cable analyses. Finite Elements in Analysis and Design 2013: 64; 79-89.

[10] Smoljanović H, Uzelac I, Trogrlić B, Živaljić N, Munjiza A. A computationally efficient numerical model for a dynamic analysis of beam type structures based on the combined finite-discrete element method. Materialwiss. Werkstofftech 2018: 49; 651-665.

[11] Bangash T, Munjiza A. Experimental validation of a computationally efficient beam element for combined finite-discrete element modelling of structures in distress. Computational Mechanics 2003, 30: 366-373.

[12] Munjiza A. The combined finite-discrete element method. UK: John Wiley \& Sons; 2004.

[13] Munjiza A, Knight EE, Rouiger E. Computational Mechanics of Discontinua. UK: John Wiley \& Sons; 2012.

[14] Munjiza A, Owen DRJ, Bicanic N. A combined finite-discrete element method in transient dynamics of fracturing solids. Engineering Computations 1995; 12: 145-174.

[15] Munjiza A, Rougier E, Knight EE. Large strain Finite element method a practical course. UK: John Wiley \& Sons; 2015.

[16] Alca N, Scott DBA, MacGregor JG. Effect of size on flexural behavior of high strength concrete beams. ACI Structural Journal 1997; 94: 59-67. 


\begin{abstract}
Sažetak
U ovom radu prezentiran je novi numerički model za analizu grednih konstrukcija. Model koristi dvočvorne konačne elemente sa translacijskim stupnjevima slobode u svakom čvoru i pri tome uzima u obzir materijalnu nelinearnost, velike pomake, velike rotacije i velike deformacije. Prezentirani numerički model je implementiran u numerički paket 'Yfdem' koji se bazira na kombiniranoj metodi konačnih i diskretnih elemenata. Prednosti novog numeričkog modela demonstrirane su na jednostavnim primjerima usporedbom rezultata s poznatim analitičkim i eksperimentalnim rješenjima iz literature.
\end{abstract}

Ključne riječi: numerički model, gredne konstrukcije, kombinirana metoda konačnih i diskretnih elemenata

\title{
Prof. DSc Ante Mihanović; ; DSc Hrvoje Smoljanović;
}

Prof. DSc Boris Trogrlić; Prof. DSc Ante Munjiza*

University of Split, Faculty of Civil Engineering, Architecture and Geodesy;

Matice hrvatske 15, 21000 Split, Croatia

* član suradnik HAZU, ${ }^{* *}$ dopisni član HAZU

corresponding author

ante.mihanovic@gradst.hr 